\title{
Myxosporean parasites of the genus Myxobolus from Mugil cephalus in Ichkeul lagoon, Tunisia: description of two new species
}

\author{
S. Bahri *, A. Marques \\ Laboratoire de Parasitologie et Immunologie, Université Montpellier II, F-34095 Montpellier Cédex 5, France
}

\begin{abstract}
Four species of the genus Myxobolus Bütschli, 1882 were recorded from Mugil cephalus in Ichkeul lagoon in northern Tunisia. Myxobolus episquamalis Egusa, Maeno \& Sorimachi, 1990 was identified as infecting scales. Myxobolus spinacurvatura Maeno, Sorimachi, Ogawa \& Egusa, 1990 was identified as parasitizing the mesenteric vessels. Myxobolus bizerti $\mathrm{n}$. $\mathrm{sp}$. was discovered in the gill filaments, while Myxobolus ichkeulensis n. sp. was found in the gill arches. Data concerning morphology, dimensions, scanning electron micrographs of the spores and ultrastructure of pansporoblast are presented.
\end{abstract}

KEY WORDS: Myxosporea Mugil cephalus Tunisia Taxonomy Myxobolus ichkeulensis n. sp. . Myxobolus bizerti n. sp.

\section{INTRODUCTION}

Mullet are one of the most important resources of the Tunisian lagoons and represent a high percentage of fishing catches. These fish are appreciated not only for their flesh but also for the female gonads.

Mugil cephalus from Tunisia have been found to be infected with several myxosporeans belonging to the genus Myxobolus Bütschli, 1882. The myxosporeans show several localizations (e.g. scales, gill arches, gill lamellae, mesenteric vessels, intestine). Previously, all of them were classified by Siau (1978) as Myxobolus exiguus.

The importance of mullets in aquaculture in some Mediterranean countries (especially Italy, Israel, Egypt and Tunisia) and the pathogenic potential of some myxosporeans, illustrated by the epizootic caused in mullet by Myxobolus exiguus in the Black Sea (Shulman 1957), induced us to compare myxosporeans parasitizing $M$. cephalus and to investigate their identity.

·E-mail: bahri@crit.univ-montp2.fr

\section{MATERIAL AND METHODS}

Between June 1994 and May 1995, 276 mullet Mugil cephalus with weights ranging from 180 to $680 \mathrm{~g}$ were collected from the Ichkeul lagoon in northern Tunisia. Fish were brought alive into the laboratory and all tissues were examined for the presence of protozoan parasites. Measurements, micrographs and line drawings of live specimens were made.

For transmission electron microscopy (TEM), cysts were fixed in $2 \% \mathrm{OsO}_{4}$ in Pallade's buffer (v/v) for $1 \mathrm{~h}$ at $4^{\circ} \mathrm{C}$. They were dehydrated and embedded in epoxy resin (Spurr), sectioned with a Reichert OMU2 microtome and stained with saturated uranyl acetate in $50 \%$ ethanol followed by lead citrate. Observations were made by a JEOL 1200-EX II transmission electron microscope.

For scanning electron microscopy, material was prefixed in $4 \%$ glutaraldehyde buffered to $\mathrm{pH} 7.4$ with $0.1 \mathrm{M}$ sodium cacodylate. It was dried in an atmosphere saturated with absolute ethanol and then dehydrated with acetone and dried with $\mathrm{CO}_{2}$ using the critical point method. The samples were finally sputter-coated with gold and observed with a JEOL JSM-35 scanning electron microscope at the University of Montpellier II. 


\section{RESULTS}

Myxosporeans were identified in developing cysts on the scales and within gill filaments, gill arches and mesenteric vessels (Figs. 1-4).

\section{Myxobolus episquamalis Egusa, Maeno \& Sorimachi, 1990}

This species forms various compact whitish masses on the distal parts of scales, with a length of 6 to $9 \mathrm{~mm}$ and a width of 4 to $6 \mathrm{~mm}$ (Fig. 1). Each cystic mass consists of numerous microcysts measuring 150 to $400 \mu \mathrm{m}$. Spores (Figs. 5a, b \& 9) are oval in front view and are tapered at the anterior end. The 2 polar capsules are pyriform. No intercapsular appendix was observed. Along the sutural edge there are 5 to 7 markings.
Spores are sometimes covered with a porous envelope of coagulated mucus. The sporoplasm is binucleate without any iodinophilous vacuole. Within the polar capsules, 5 or 6 filament coils were observed. The 2 orifices of polar filaments are elongated and symmetrical with regard to the sutural line (Fig. 13). We identify this parasite as the species $M$. episquamalis.

\section{Diagnosis: Host: Mugil cephalus}

Locality: Ichkeul lagoon (Bizerte), Tunisia Site of infection: scales

Prevalence: 5 of 276 specimens examined Fresh spore measurements $(n=40)$ Length: $8.5(8-9) \mu \mathrm{m}$ Width: $6.5(6-7) \mu \mathrm{m}$

Polar capsules: length $4(3.5-4.5) \mu \mathrm{m}$ width $2(1.5-2.5) \mu \mathrm{m}$

Number of polar filament turns: $5-6$
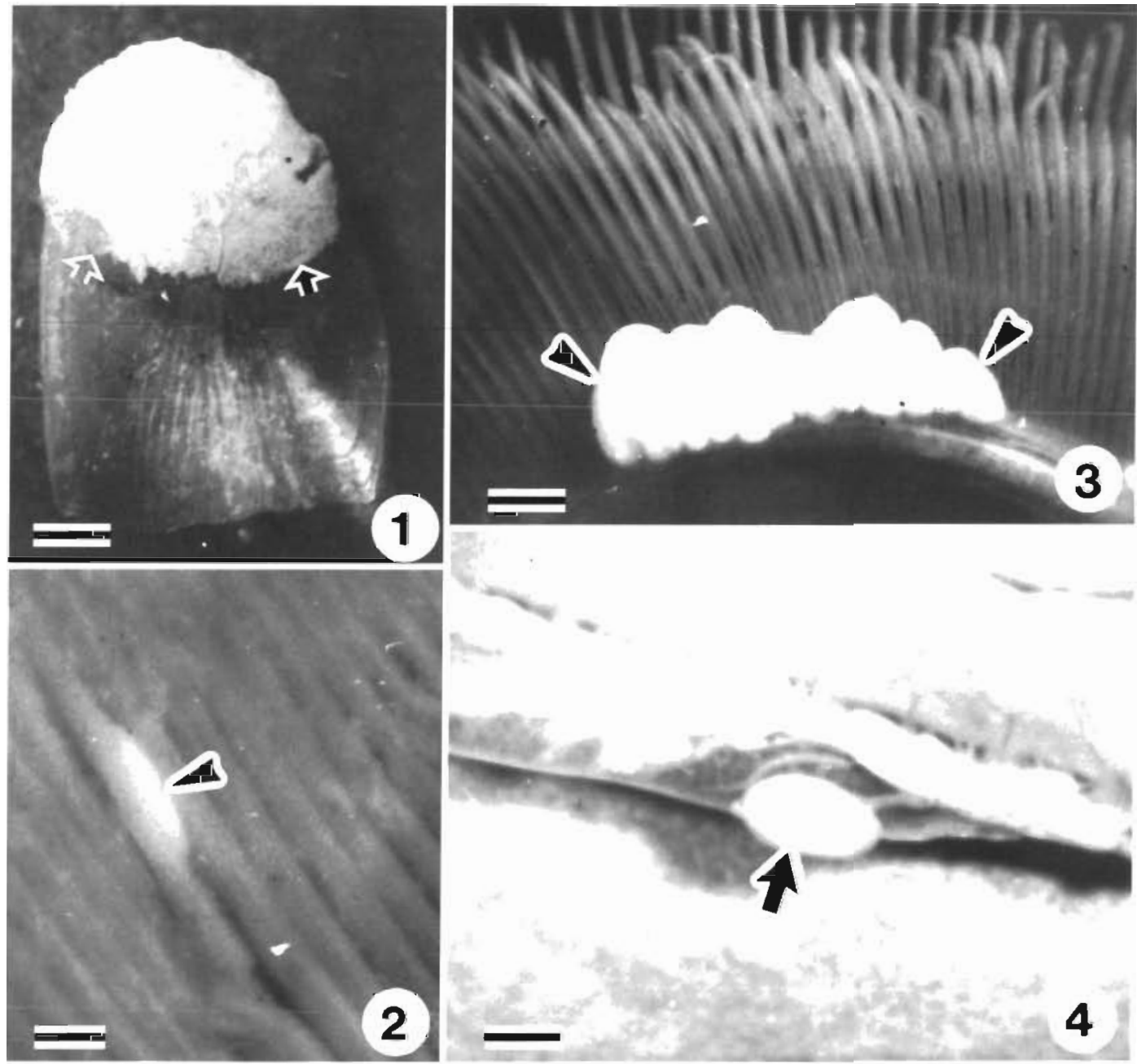

Figs. 1 to 4. Myxobolus spp. Different localizations of myxosporeans on Mugil cephalus. Fig. 1. Scale bearing a cyst (arrows) of M. episquamalis on the apical area (bar $=2 \mathrm{~mm}$ ). Fig. 2. Elongated cyst (arrow) on gill filament (bar $=0.5 \mathrm{~mm}$ ). Fig. 3 . Aligned cystic masses (arrows) at the base of gill arch (bar $=4 \mathrm{~mm}$ ) Fig. 4 . Cyst (arrow) of $M$. spinacurvatura in the mesenteric vessel wall $(\overline{\text { bar }}=1 \mathrm{~mm})$ 


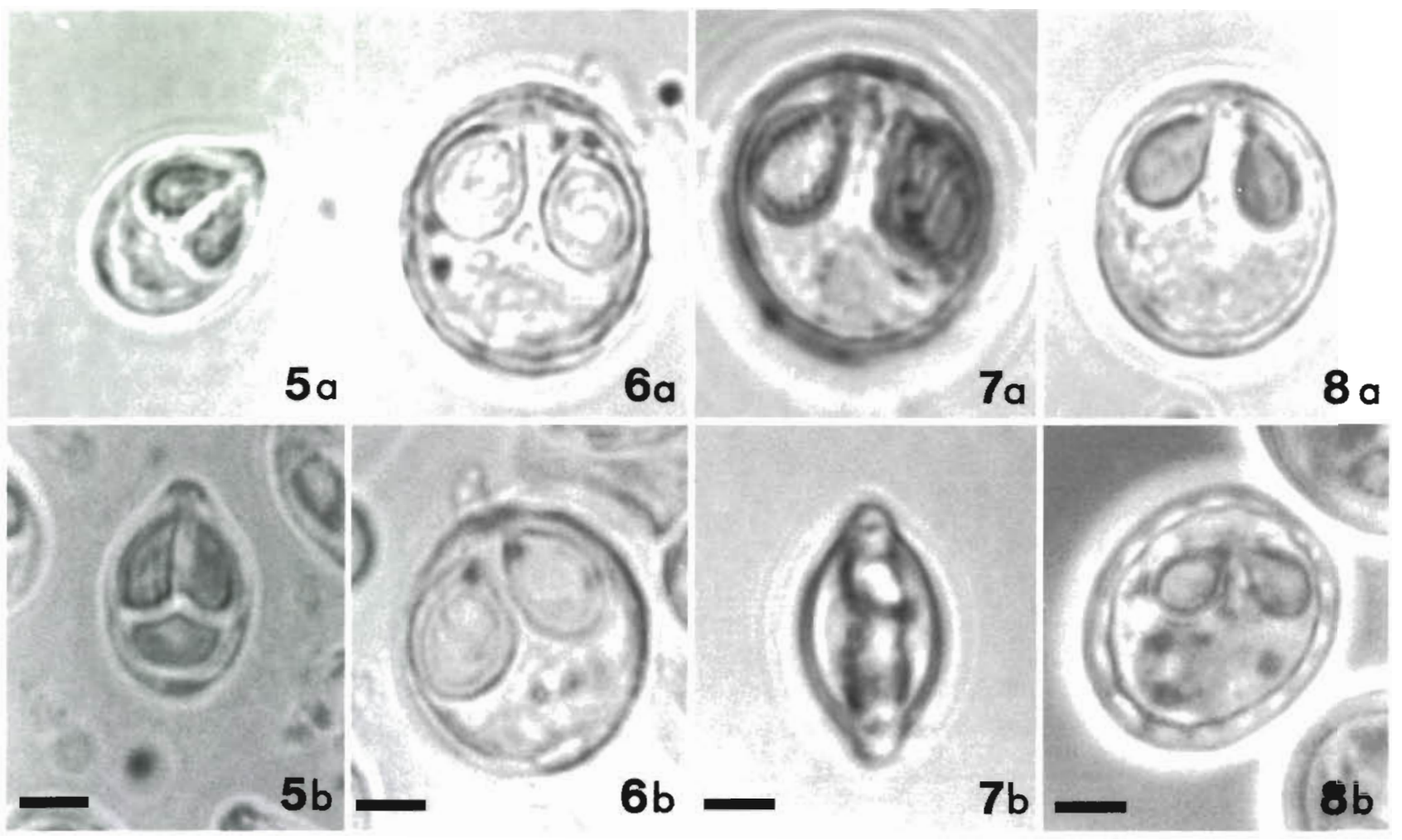

Figs. 5 to 8. Myxobolus spp. Mature spores from fresh preparations. Fig. 5a, b. M. episquamalis in front view (bar $=3 \mu \mathrm{m}$ ) Fig. $6 \mathrm{a}, \mathrm{b} . M$. ichkeulensis $\mathrm{n}$. $\mathrm{sp}$. in front view (bar $=3.5 \mu \mathrm{m}$ ). Fig. 7 . M. bizerti $\mathrm{n}$. $\mathrm{sp}$. in front view (a) and in side view (b) $(\mathrm{bar}=3.5 \mu \mathrm{m})$. Fig. $8 \mathrm{a}, \mathrm{b} . \mathrm{M}$. spinacurvatura in front view. Note the presence of numerous sutural markings (bar $=3 \mu \mathrm{m}$ )

\section{Myxobolus bizerti n. sp.}

In primary gill lamellae, the parasite forms elongated plasmodia appearing as cysts (Fig. 2) measuring 0.22 to $2.3 \mathrm{~mm}$ in length and 0.4 to $0.8 \mathrm{~mm}$ in width. Spores (Figs. 7 a, b \& 11) are mostly spherical. There are 8 to 11 sutural markings along the sutural edge. The polar capsules are pyriform and converge at their anterior pointed tips which do not show an intercapsular appendix. The capsules exceed the mid-length of the spore with their posterior ends. They show 6 to 7 filament coils. The discharging orifices of both polar filaments are circular and slightly displaced (Fig. 14). The sporoplasm is small and bi- nucleate, without any iodinophilous vacuole. Based upon its location and morphological characteristics, this parasite proves to be a new species. We propose the name $M$. bizerti $\mathrm{n}$. sp.

\section{Diagnosis: Host: Mugil cephalus}

Locality: Ichkeul lagoon (Bizerte), Tunisia

Site of infection: gill lamellae

Prevalence: 24 of 276 specimens examined

Fresh spore measurements $(n=30)$

Diameter $14.25(14-14.5) \mu \mathrm{m}$

Polar capsules: length $6.5(6-7) \mu \mathrm{m}$ width $5.75(5.5-6) \mu \mathrm{m}$

Number of polar filament turns: $6-7$
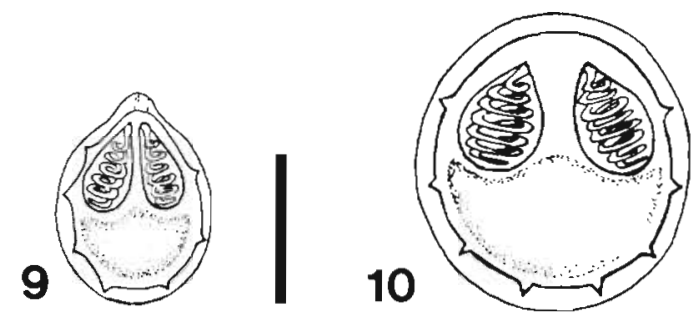

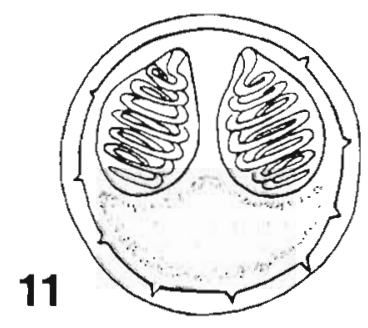

12

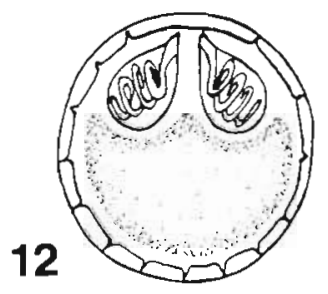

Figs. 9 to 12. Myxobolus spp. Line drawings of mature spores. Fig. 9. M. episquamalis. Fig. 10. M. ichkeulensis n. sp. Fig. 11. M. bizerti n. sp. Fig. 12. M. spinacurvatura. (Bar $=7 \mu \mathrm{m})$ 

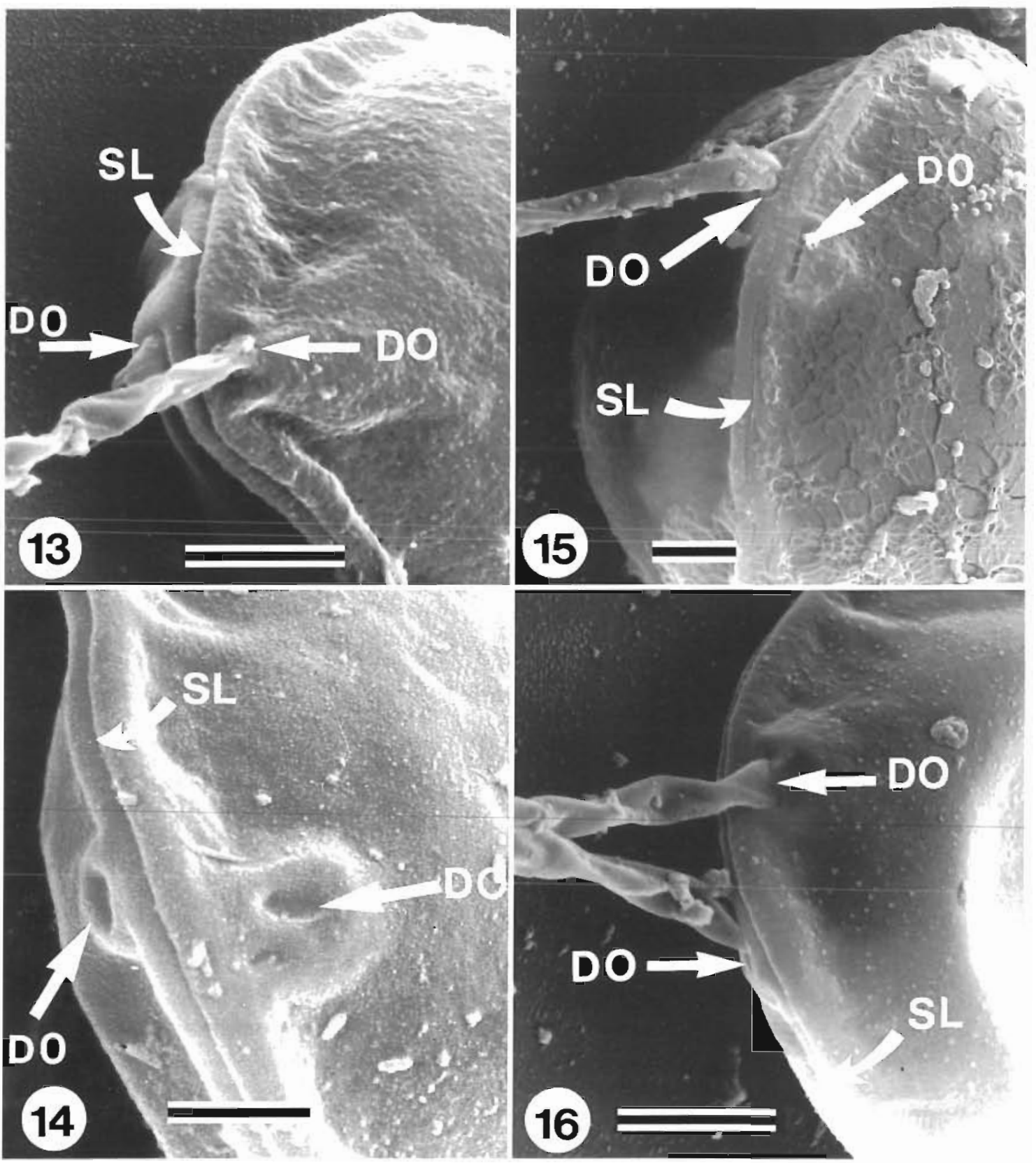

Figs. 13 to 16. Myxobolus spp. Scanning electron micrographs of the anterior end of the spore. Note shape, position of discharging orifices of polar filaments (DO) and sutural line (SL). Fig. 13. M. episquamalis. Fig. 14. M. bizerti n. sp. Fig. 15. M. ichkeulensis n. sp. Fig. 16. M. spinacurvatura. (Bars $=1 \mu \mathrm{m})$

\section{Myxobolus ichkeulensis n. sp.}

Myxosporeans infecting gill arches (Fig. 3) were clustered as cystic masses $(2.2$ to $4 \mathrm{~mm}$ in length and 1 to $3 \mathrm{~mm}$ in width) at the base of filaments. Spores (Figs. 6a, b \& 10) are quite sphericali they present 9 to 11 sutural markings. Polar capsules are oval in shape and reach with their posterior end to half the length of the spore. No intercapsular appendix was visible be- tween the anterior ends of the polar capsule. Polar filaments are coiled in 7 to 8 turns; their discharging orifices situated on both sides of sutural line are elongated and close together (Fig. 15). The sporoplasm situated at the posterior end of the spore fills half of the spore length. There is no iodinophilous vacuole. Based upon its location and morphological characteristics, this parasite proves to be a new species. We propose the name $M$. ichkeulensis $\mathrm{n} . \mathrm{sp}$ 


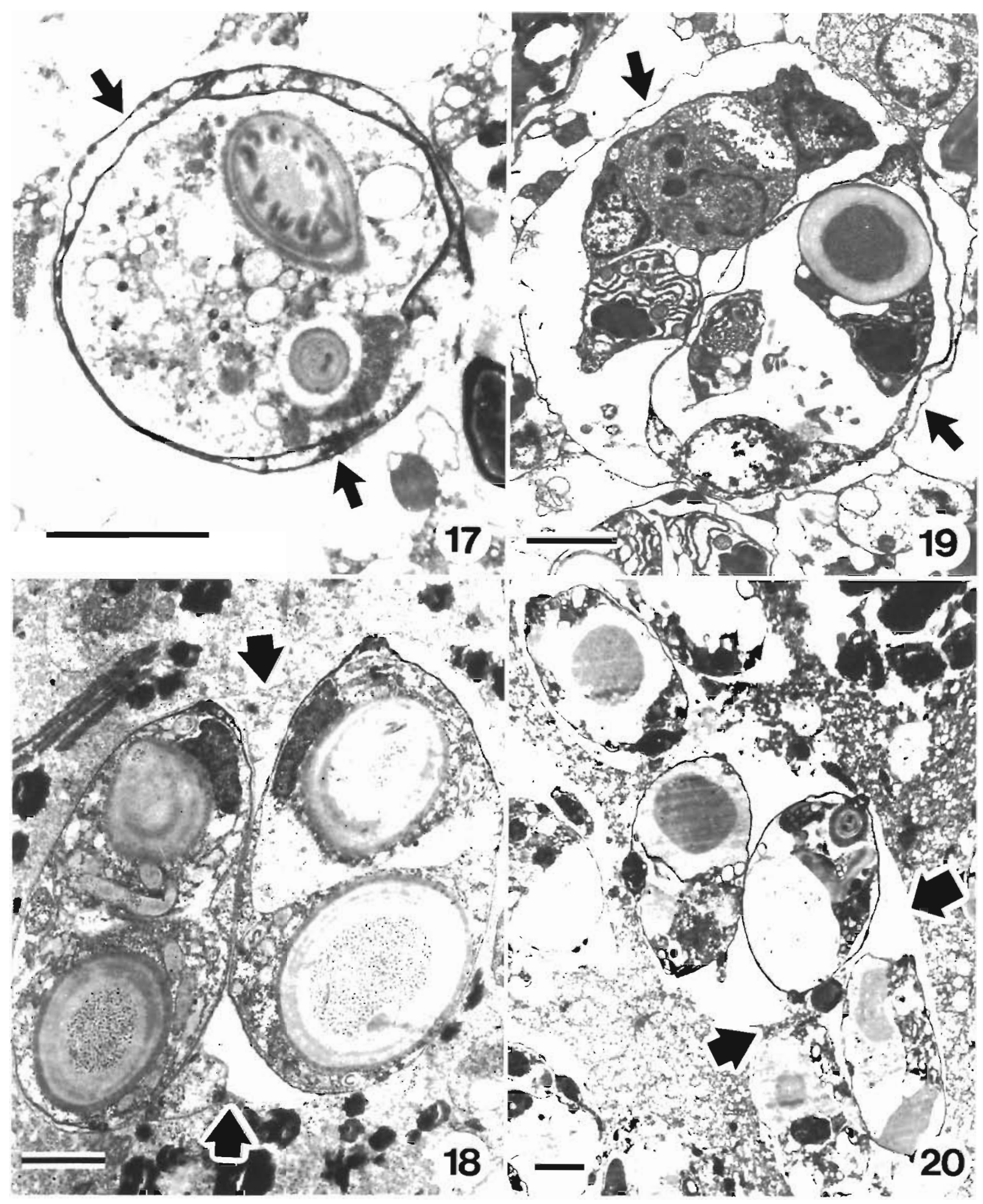

Figs. 17 to 20. Myxobolus spp. Ultrastructure of pansporoblast. Fig. 17. Monosporous pansporoblast of $M$. episquamalis (arrows point at the pericyte). Figs. 18 \& 19. Disporous pansporoblasts (arrows) respectively of $M$. bizerti $\mathrm{n}$. sp. and $M$. spinacurvatura. Fig. 20. Folysporous pansporoblast (arrows) of $M$. ichkeulensis n. $\mathrm{sp}$. (Bars $=2 \mu \mathrm{m})$ 
Diagnosis: Host: Mugil cephalus

Locality: Ichkeul lagoon (Bizerte), Tunisia

Site of infection: gill arches

Prevalence: 18 of 276 specimens examined

Fresh spore measurements $(\mathrm{n}=30)$

Length: $13.5(13-14) \mu \mathrm{m}$

Width: $12.5(12-13) \mu \mathrm{m}$

Polar capsules: length $5.5(5-6) \mu \mathrm{m}$

width $4.15(4-4.3) \mu \mathrm{m}$

Number of polar filament turns: $7-8$

\section{Myxobolus spinacurvatura Maeno, Sorimachi, Ogawa \& Egusa, 1990}

The walls of mesenteric vessels in Mugil cephalus often bore isolated cysts of a myxosporean (Fig. 4) which were oval or spherical in shape, 0.2 to $3.8 \mathrm{~mm}$ in length and 0.2 to $3.3 \mathrm{~mm}$ in width. Spores released at maturity (Figs. 8a, b \& 12) are regularly ellipsoidal in front view. Small numerous sutural markings (12 to 14 in number) are present over the sutural edge. Polar capsules are oval-shaped and their posterior ends do not reach the midpoint of the spore length. No intercapsular appendix appears. Each polar filament is coiled in 4 or 5 turns. Their discharging orifices (Fig. 16) are round in shape and slightly displaced with regard to the spore long axis. A binucleate sporoplasm fills more than a half of the sporal cavity. No iodinophilous vacuole was observed. We identify this parasite as the species $M$. spinacurvatura.

Diagnosis: Host: Mugil cephalus

Locality: Ichkeul lagoon (Bizerte), Tunisia

Site of infection: mesenteric vessels

Prevalence: 87 of 276 specimens examined

Fresh spore measurements $(\mathrm{n}=30)$

Length: $12(11-13) \mu \mathrm{m}$

Width: $10(9-11) \mu \mathrm{m}$

Polar capsules: length $4.75(4-5.5) \mu \mathrm{m}$ width $2.75(2-3.5) \mu \mathrm{m}$

Number of polar filament turns: $4-5$

\section{Sporogenesis}

Data obtained from transmission electron microscopy allowed us to compare the sporogenesis of these different myxosporeans. Several plasmodia were examined for each species. The pansporoblast of $\mathrm{MyxO}-$ bolus episquamalis infecting the scales is monosporous (Fig 17); those of $M$. bizerti n. sp. and $M$. ichkeulensis $\mathrm{n}$. sp. parasitizing respectively the gill lamellae (Fig 18) and the mesenteric vessels (Fig. 19) are disporous. However, the pansporoblast of $M$. spinacurvatura on gill arches is polysporous (Fig. 20).

\section{DISCUSSION}

According to our knowledge 11 species (Table 1) belonging to the Myxobolus genus have been described infecting Mugil cephalus (Kudo 1920, Shulman 1966, Iversen et al. 1971, Egusa et al. 1990, Maeno et al. 1990, Landsberg \& Lom 1991, Lom \& Dykova 1992, 1994). Most of them can be clearly distinguished from each other.

Myxobolus species infecting the scales of Mugil cephalus have been reported in Tunisian costal waters (Siau 1978), and were attributed to Myxobolus exiguus Thélohan, 1895. They were also mentioned along the Mediterranean coast of Israel (Overstreet \& Howse 1977), in the Atlantic at Ria de Aveiro in northern Portugal (Menezes 1984), and in Japanese coastal waters (Egusa et al. 1989). Egusa et al. (1990) established a new species, Myxobolus episquamalis. This species seems to be similar with respect to its infection site, shape and size to our findings on Mugil cephalus from Tunisia (Bahri et al. 1995). Lom \& Dykova (1992) considered it to be a junior synonym of $M$. exiguus. However, except for the species found on the scales in our study, the Myxobolus spores found in the other sites did not have morphological characteristics similar to M. exiguus.

Six species of Myxobolus have previously been identified from the gills of Mugil cephalus. M. mülleri Bütschli, 1882 has spherical spores in front view with an intercapsular appendix. Spores of $M$. exiguus Thélohan, 1895 and $M$. achmerovi Shulman, 1966 are oval and anteriorly tapered with distinct small intercapsular process. M. branchialis Markevitch, 1932 and M. parvus Shulman, 1962 have ellipsoidal spores with an intercapsular appendix.

In their shape and size (Table 1), $M$. bizerti n. sp. differs from the above Myxobolus species. M. mugcephalus Landsberg \& Lom, 1991 shows similarities with $M$. bizerti n. sp. with respect to its circular shape; however, its spores $(4.8$ to $5.2 \mu \mathrm{m}$ ) are noticeably smaller than those of our species.

Myxobolus cephalis Iversen, Chitty \& Van Meter, 1971 has been described as infecting various organs of sea mullet including gill arches in South Florida waters. The spores of this species, however, have a slightly smaller length (14 to $15 \mu \mathrm{m}$ ) and smaller width (10 to $11 \mu \mathrm{m}$ ) than those of $M$. ichkeulensis $\mathrm{n}$. sp. and they have no sutural markings. In addition, the number of filament turns is lower ( 4 to 5 ) than in our species ( 7 to 8 ). These data indicate important differences from our findings

The Myxobolus sp. we describe from the mesenteric vessels has approximatively the same size as $M$. achmerovi Shulman, 1966. The latter was first identified by Akhmerov (1960) from fins, gills and the mesentery 
Table 1. Comparison of spore dimensions (in $\mu \mathrm{m}$ ) between Myxobolus species infecting Mugil cephalus

\begin{tabular}{|c|c|c|c|c|c|}
\hline \multirow{2}{*}{ Species } & \multirow[t]{2}{*}{ Localization } & \multicolumn{2}{|c|}{ Spore } & \multicolumn{2}{|c|}{ Polar capsule } \\
\hline & & Length & Width & Length & Width \\
\hline M. mülleri Bütschli, 1882 & Gill filaments & $10-12$ & $9-11$ & $4-5$ & $2-3$ \\
\hline M. exiguus Thélohan, 1895 & $\begin{array}{l}\text { Gill filaments } \\
\text { Tissue of stomach } \\
\text { Pyloric caeca }\end{array}$ & $8-9.5$ & $6-7.5$ & $3-4.5$ & $1.5-3$ \\
\hline M. branchialis (Markevitch, 1932) & Gill filaments & $8-7.6$ & $6.8-8.5$ & $4.4-4.8$ & $2.5-4.1$ \\
\hline M. parvus Shulman, 1962 & Gill lamellae & $6.5-7$ & $5.5-6$ & $4-4.2$ & $3.8-4.2$ \\
\hline M. cheni Shulman, 1962 & Muscles & $8-8.5$ & $6-6.5$ & $4.5-5$ & 2 \\
\hline M. achmerovi Shulman, 1966 & $\begin{array}{l}\text { Fins } \\
\text { Mesentery }\end{array}$ & $12-14$ & $9-10$ & $4-5.3$ & $2.3-3.5$ \\
\hline $\begin{array}{l}\text { M. cephalis Iversen, } \\
\text { Chitty \& Van Meter, } 1971\end{array}$ & $\begin{array}{l}\text { Brain meninges } \\
\text { Gill arches } \\
\text { Buccal cavity } \\
\text { Jaw bone }\end{array}$ & $14-15$ & $10-11$ & $4-5$ & $3-4$ \\
\hline $\begin{array}{l}\text { M. episquamalis } \\
\text { Egusa, Maeno \& Sorimachi, } 1990 \\
\text { (junior synonym of M. exiguus) }\end{array}$ & Scales & $7.5-9.5$ & $6-7.5$ & $3.8-5$ & $2-3$ \\
\hline $\begin{array}{l}\text { M. spinacurvatura } \\
\text { Maeno, Sorimachi, Ogawa \& Egusa, } 1990\end{array}$ & $\begin{array}{l}\text { Mesentery } \\
\text { Brain }\end{array}$ & $10.5-12.5$ & $9-11$ & $3.5-5$ & $2.5-3.5$ \\
\hline $\begin{array}{l}\text { M. mugcephalus } \\
\text { Landsberg \& Lom, } 1991\end{array}$ & Gill filaments & 4.8 & 5.2 & & \\
\hline M. rohdei Lom \& Dykova, 1994 & Kidney & $9.8-11.6$ & $8.4-9.1$ & $3.7-5$ & $2.5-3.1$ \\
\hline
\end{tabular}

of common carp in the Amur region (eastern Russia) as M. oviformis Thélohan, 1892 and then reclassified as Myxobolus sp. by Shulman \& Shtein (1962). Shulman (1966) established it as a new species, M. achmerovi Shulman, 1966, including in its host range Mugil cephalus and $M$. soiuy without further explanation. Thus we cannot compare it with our finding. However, M. spinacurvatura Maeno, Sorimachi, Ogawa \& Egusa, 1990 observed in the mesentery and brain of Mugil cephalus has spores with a size and shape comparable to our finding. In order to prevent possible creation of synonyms, we have considered our finding as probably identical with $M$. spinacurvatura.

\section{CONCLUSION}

In the past, morphological critera of myxosporeans have been considered sufficient to group species under the same taxonomic entity infecting hosts even when they were found in different geographical locations and in different tissues, as long as the spores were similar. Currently, 2 approaches are used. The first case is that of myxosporeans parasitizing different hosts but inducing the same pathology; they should be grouped as the same entity as least until the alternate stage (actino-myxosporidian) is described. The second case is that of myxosporeans infecting the same host but in different tissues and presenting spores with distinct morphological characteristics. They probably cor- respond to unique species. We use the latter approach to the classification of myxosporean species of the genus Myxobolus parasitizing Tunisian Mugil cephalus, species which in the past have been attributed to Myxobolus exiguus. It would appear from our study that different species were present, of which 2 are new.

The presence of 4 species in Mugil cephalus from Tunisia emphasizes the importance of tissue tropism in these species and proves again that myxosporeans are tissue-specific parasites, i.e. they always develop in a specific host tissue. An example is Myxobolus cerebralis, which migrates between the epidermal cells of rainbow trout to reach the cartilage via peripheral nerves and central nervous system (El-Matbouli et al. 1995). In addition, the pathogenic effects of the species we found are variable. $M$. episquamalis can invade the whole body of mullet, debilitating it and leading to its commercial rejection. $M$. ichkeulensis n. sp. weakens the cartilaginous tissue of gill arches, while the cysts of M. bizerti n. sp. are liable to block the lumen of the blood vessels of the gill lamellae.

\section{LITERATURE CITED}

Akhmerov K (1960) Myxosporidia of fishes from the Amur river basin. Rybn khoz vnutr vodoiemov LatSSR 5: 240-307 (in Russian)

Bahri S, Marques A, Coste F, Bouix G, Ben Hassine OK (1995) Presence of a cutaneous myxosporidian in Tunisian Mugil cephalus (Linnaeus, 1758). Bull Eur Ass Fish Pathol 15(2): $54-57$ 
Egusa S, Jyo Y, Oka H, Ikata K (1989) Skin disease of Mugil cephalus sp. (Myxozoa: Myxobolidae). Fish Pathol 24: $59-60$

Egusa S, Maeno $Y$, Sorimachi M (1990) A new species of Myxozoa, Myxobolus episquamalis sp. n. infecting the scales of the mullet, Mugit cephalus L. Fish Pathol 25: $87-91$

El-Matboul M, Holtman RW, Mandok C (1995) Light and electron microscopic observations on the route of the triactinomyxon-sporoplasm of Myxobolus cerebralis from epidermis into rainbow trout cartılage. J Fish Biol 46:919-935

Iversen ES, Chitty N, Van Meter N (1971) Some Myxosporidia from marine fishes in south Florida. J Protozool 18:82-86

Kudo RR (1.920) Studies on Myxosporidia. A synopsis of genera and species of Myxosporidia. Ill Biol Monog 5:1-265

Landsberg JH. Lom J (1991) Taxonomy of the genera of the Myxobolus/Myxosoma group (Myxobolidae: Myxosporea) current listing of species and revision of synonyms. Syst Parasitol 18:165-186

Lom J, Dykova I (1992) Protozoan parasites of fishes. Developments in aquaculture and fisheries science, Vol 26. Elsevier, Amsterdam

Lom J, Dykova I (1994) Studies on Protozoan parasites of Australian fishes III. Species of genus Myxobolus Bütschli,

Responsible Subject Editor: O. Kinne, Oldendorf/Luhe, Germany
1882. Eur J Protistol 30:431-439

Maeno Y, Sorimachı M, Ogawa K. Egusa S (1990) Myxobolus spinacurvatura sp. n. (Myxosporea: Bivalvulida) parasitic in detormed mullet, Mugil cephalus. Fish Pathol 25:37-41 (in Japanese)

Menezes J (1984) A case of massive cutaneous myxobolosis in wild mullet. Bol Inst Nac Invest Pescas (12):71-73

Overstreet RM. Howse HD (1977) Some parasites and diseases of estuarine fishes in polluted habitats of Mississippi. Ann NY Acad Sci 298:427-462

Shulman SS (1957) Note sur la pathogenese de la Myxosporidie Myxobolus exiguus et sur les épizooties dues à ce parasite. Bull Inst Rech 42:1-328 (in Russian)

Shulman SS (1966) Myxosporidians in the fauna of the USSR Nauka, Moscow-Leningrad (in Russian)

Shulman SS, Shtein GA (1962) Protozoa. In: Bykhovsky BE (ed) Key to determination of parasites of freshwater fish of the USSR. Acad Sci Publishing House, MoscowLeningrad, p 8-197 (in Russian)

Sıau Y (1978) Contribution à la connaissance des Myxosporidies: étude de Myxobolus exiguus Thélohan, 1985 (cytologie, cycle, actions sur l'hote, epidemiologie). Thesis USTL (Université Sciences et Techniques du Languedoc), Montpellier II

Manuscript first received: March 7, 1996

Revised version accepted: June 18, 1996 